\title{
International Criminal Court in the Trenches of Africa
}

\author{
Lydia A. Nkansah*
}

\begin{abstract}
The pursuit of international criminal justice in Africa through the International Criminal Court (ICC) platform has not been without hitches. There is a rift between the African Union (AU), as a continental body, and the ICC owing to the $A U$ 's perception that the ICC is pursuing selective justice and the AU's misgivings about the ICC's indictment /trial of some sitting heads of states in Africa. This article argues that the claim of selective justice cannot be dismissed because it undermines the regime of international criminal justice. The indictment/trial of serving heads of states also has serious constitutional and political implications for the countries involved, but this has been ignored in the literature. Further, the hitches arise both from the failure of the ICC to pay attention to the domestic contexts in order to harmonize its operations in the places of its interventions and from the inherent weakness of the ICC as a criminal justice system. The ICC, on its part, insists that any consideration given to the domestic contexts of its operations would undermine it. Yet the ICC's interventions in Africa have had serious political, legal and social implications for the communities involved, jeopardizing the peaceful equilibrium in some cases. This should not be ignored. Using the law to stop and prevent international crimes in African societies would require a concerted effort by all concerned to harmonize the demand for justice with the imperatives on the ground.
\end{abstract}

Keywords: Africa and International Criminal Court, Amnesty and war crimes, International Criminal Court, International criminal justice, Peace agreements.

\section{Introduction}

The Rome Statute of the International Criminal Court (ICC) recognizes "that during this century millions of children, women and men have been victims of unimaginable atrocities that deeply shock the conscience of humanity" owing to armed conflicts. These "grave crimes threaten the peace, security and well-being of the

* $\quad$ LL.B, LL.M (Bendel State University), BL (Ghana \& Nigeria), PhD (Walden University) is Senior Lecturer, Faculty of Law, Kwame Nkrumah University of Science and Technology, Kumasi, Ghana. The section of the article under the subheading "Putting the ICC in the Domestic Contexts of its Operation" is partly based on some ideas from the author's PhD dissertation titled 'Transitional Justice in Postconflict Contexts: The Case of Sierra Leone's Dual Accountability Mechanisms', submitted to Walden University, 2008. 
world". ${ }^{1}$ Africa has had its fair share of the problem. ${ }^{2}$ As such, various efforts to pursue, make and keep the peace have been intensified over the past half a century. One of the emerging trends of a unique texture of peace and the peculiar means for attaining peace is to punish certain actions and omissions that are considered international crimes wherever they may take place on the continent.

The ICC is a permanent international criminal court established to prosecute international crimes. It is based on the idea that "most serious crimes of concern to the international community as a whole must not go unpunished", ${ }^{3}$ and that the international community is "determined to put an end to impunity for the perpetrators of these crimes and thus to contribute to the prevention of such crimes". ${ }^{4}$ It is believed that if the atrocities committed after the Nuremberg trials had been prosecuted, some of the carnage the world had experienced after the Nuremberg trials would have been prevented or averted.

The ICC has been invoked in respect of some conflict situations in Africa. The pursuit of international criminal justice in Africa through the ICC platform has not been without hitches. There is a rift between the African Union (AU), as a continental body, and the ICC owing to the AU's perception of the ICC as pursuing selective justice. ${ }^{5}$ Some state parties in Africa have also refused or failed to comply with their obligations to cooperate with the ICC under the Rome Statute. ${ }^{6}$ Critics have argued that it has impeded the peace-building process in some of the countries involved. The ICC's indictments have created tensions and aggravated conflicts and humanitarian situations in places such as Uganda and Sudan, Darfur. Cobban and Geis and Mundt reported that the Lord's Resistance Army intensified their attacks against the civilian population and aid workers ${ }^{7}$ as a reaction to the ICC's indictment of its leaders. Further, the Lord's Resistance Army (LRA) also backed out of the peace process, claiming that a ceasefire would be misinter-

1 Preamble to the Rome Statute of the International Criminal Court (hereinafter the 'Rome Statute'), 1998. U.N. Doc. A/CONF.183/9*. Retrieved on 3 May 2014 from <www. un. org/law/icc/ statute/romefra.htm>, paras. 2 and 3.

2 In the conflicts in Sierra Leone, Liberia, Uganda, Kenya, Sudan, Rwanda, Cote d'Ivoire, Democratic Republic of Congo and others, women were subjected to rape, sexual slavery and other forms of sexual abuses. Others were amputations and killings.

3 Para. 4 of the Preamble to the Rome Statute.

4 Para. 5 of the Preamble to the Rome Statute.

5 See C.C. Jalloh, 'Regionalizing International Criminal Law?', International Criminal Law Review, Vol. 9, 2009, pp. 445-499; C.C. Jalloh, D. Akande \& M. du Plessis, 'Assessing the African Union Concerns About Article 16 of the Rome Statute of the International Criminal Court', African Journal of Legal Studies, Vol. 4, 2011, pp. 5-50; G.P. Barnes, 'The International Criminal Court's Ineffective Enforcement Mechanisms: The Indictment of President Omar Al Bashir', Fordham International Law Journal, Vol. 34, No. 6, 2011, pp. 1584-1619, where the impasse between the AU and Africa is discussed in detail.

6 Id.

7 H. Cobban, 'Think Again: International Courts', Foreign Policy, 2006, pp. 22-28; J. Geis \& A. Mundt, 'When to Indict? The Impact of Timing of International Criminal Indictment on Peace Processes and Humanitarian Action', The Brookings Institution-University of Bern Project on Internal Displacement, Paper for the World Humanitarian Studies Conference, Groningen, The Netherlands, February 2009 
preted by the ICC and government as occasioned by the indictments. ${ }^{8}$ Similarly, the International Crisis Group reported that the indictment of Al-Bashir disrupted the peace process in Sudan. ${ }^{9}$ Al-Bashir's indictment led to the expulsion of UN forces and thirteen non-governmental organizations that had been providing humanitarian assistance since 2003 on the allegation that they were working for the ICC, ${ }^{10}$ worsening the humanitarian crises. Others have called for the need for the ICC to pay attention to the domestic contexts of its interventions in terms of timing ${ }^{11}$ and political expediency. Mahmood Mandani, for example, maintained that perpetrators of atrocities in Darfur should be held accountable, but "when and how are political decisions that cannot belong to the ICC prosecutor. More than the innocence or guilt of the President of Sudan, it is a relationship between law and politics". ${ }^{12}$ The ICC is accused of being "part of a new mechanism of neocolonialism". ${ }^{13}$ Supporters of the ICC and in particular those in favour of the indictment of the Sudanese president maintained that the ICC's intervention is a right step towards the realization of human dignity, addressing impunity, facilitating democracy and peace, and for ensuring justice for the victims. ${ }^{14}$ That the indictment will serve as a deterrence against future abuses and prevent further killings. ${ }^{15}$

Against this background, this article argues that aside from the refusal or failure of the AU and some African States Parties to cooperate with the ICC, part of the problem is due to the failure of the ICC to pay attention to the local contexts in order to harmonize its operations in the places of its intervention. However, the ICC maintained that any consideration given to the local situation will undermine the Court. ${ }^{16}$ Yet the ICC's interventions in Africa have had serious political,

8 Geis \& Mundt, 2009.

9 International Crisis Group, cited in D.E. Arzt, 'Views on the Ground: The Local Perception of International Tribunals in the Former Yugoslavia and Sierra Leone', The ANNALS of the American Academy of Political and Social Science, Vol. 603, No. 226, 2006, pp. 226-239.

10 M. Ssenyonjo, 'The International Criminal Court and the Warrant of Arrest for Sudan's President Al-Bashir: A Crucial Step Towards Challenging Impunity or a Political Decision', Nordic Journal of International Law, Vol. 78, 2009, pp. 397-431; see also K.G. Adar, 'The International Criminal Court and the Indictment of President Omar al-Bashir: Implications for Sudan and Africa', AISA Policy Brief, No. 10, February 2010.

11 Geis \& Mundt, 2009; L.A. Nkansah, 'The International Criminal Justice in Africa: Some Emerging Dynamics', Journal of Politics and Law, Vol. 4, No. 2, 2011, pp. 74-84.

12 See M. Mamdani, 'Darfur, ICC and the New Humanitarian Order', Pambazuka News, 2008-9-7. Retrieved on 24 July 2014 from <www.pambazuka.org/en/category/comment/50568>.

13 Ssenyonjo, 2009, p. 397.

14 See A. de Waal, 'Sudan and the International Criminal Court: A Guide to Controversy. Retrieved on 21 October from <http://.opendemocracy.net/article/sudan-and-the-international-criminalcourt-a-guide-to-the-controversy $>$.

15 G. Gagnon, 'The Collective International Responsibility to Protect: The Case of Darfur', 4 Nw.U. J.Int'I Hum. Rts, 121 (2005).

16 See Address by L. Moreno-Ocampo, First Prosecutor of the International Criminal Court at the International Conference on "Building a Future on Peace and Justice", held at Nuremberg, 25-27 June 2007, pp. 3-4. Retrieved on 14 August 2014 from <www. peace-justice-conference. info/ download/speech\%20moreno.pdf $>$. 
legal and social implications for the communities involved that should not be ignored.

The article further argues that the ICC, being a permanent institution, is likely to coexist and operate alongside with other domestic juridical bodies in the places of their intervention. There may be national trials involving war crimes, truth commissions or existing peace agreements with amnesties at the national level. It is critical that the ICC coordinates its plans taking into consideration these other bodies with the understanding that they are different parts of the same tool. Likewise, state parties should ensure that in mandating truth commissions, peace agreements, etc. they do not undermine their obligations to the ICC. A coordination arrangement between ICC and the states concerned would be needed; otherwise the ICC and these other bodies will be pitted against each other, undermine their respective mandates and create tensions in their efforts to implement their plans.

Against this background, this article examines how the ICC has resonated in the trenches of Africa and how it can contextualize its intervention to make a positive contribution. The article will draw on the knowledge derived from the experiences of the ad hoc tribunals to suggest the way forward for the ICC. This study aims to contribute to an understanding of the impact of the ICC on the domestic settings of the places of their interventions, to inform its future endeavours. In terms of its organization, the article discusses the impasse that the interventions have created, analyses the domestic contexts of the ICC's interventions and their implications and draws conclusions and makes recommendations.

\section{ICC's Engagement in Africa}

The ICC's indictments to date are only in connection with alleged offences regarding the conflict situations in Africa, namely Uganda, Central African Republic (CAR), Democratic Republic of Congo (DRC), Sudan, Republic of Kenya, Libya, Cote D'Ivoire and Mali. The ICC came to be seized with these cases through referrals from governments and the UN Security Council and by the Prosecutor's investigations. The cases are currently at different stages of investigation/trial, with only one concluded. The Rome Statute is very active and operative in Africa. It should be noted that Africa was the foremost in providing support for the ICC and that Senegal was the first country to ratify the ICC Statute. ${ }^{17}$ Some African governments and individuals have cooperated with the ICC, while others, such as Sudan, have refused to cooperate; Uganda cooperated but was unable to comply with its treaty obligations to hand over indictees in their territory to the ICC. The AU has fiercely opposed the ICC's operations in African situations and has threatened to get its members to withdraw from the ICC and asked its member states

17 See C.C. Jalloh, 'Regionalizing International Criminal Law?', International Criminal Law Review, Vol. 9, 2009, pp. 445-499; see also C.C. Jalloh, D. Akande \& M. du Plessis, 2011 on the history of Africa's support for the ICC. 
not to cooperate with the ICC. ${ }^{18}$ There is an impasse between the AU and the ICC because, first, the AU has accused the ICC of engaging in selective justice in that the ICC indictments relate to only African situations and only Africans are being pursued so far. ${ }^{19}$ Second, the AU has raised concerns about the indictment/trial of sitting African heads of state. The implication of the impasse is that some of the indictees are at large and state parties have failed or refused to carry out the ICC's request to arrest them. The ICC Prosecutor expressed its predicament with regard to the lack of cooperation in getting recalcitrant indictees arrested. ${ }^{20}$ In what follows, these issues are discussed in detail.

\subsection{The Issue of Selective Justice}

First, the crucial issue to consider and confront on selective justice is whether the crimes for which the ICC has intervened in African situations are indeed covered by the Rome Statute; in other words, whether crimes within the ICC's jurisdiction are occurring or have occurred. Further, it needs to be questioned whether the governments with the primary responsibility to hold perpetrators accountable for such crimes are unwilling or unable to do so and thereby warrant ICC's intervention. Undoubtedly, the ICC has intervened in the situations under consideration because crimes within its jurisdiction have been committed in those places. For example, it is estimated that in the conflict in Darfur, Sudan, at a given period during the conflict 5,000 people died every month, 35,000 people died due to attacks and 300,000 of those who fled from the attacks died of starvation. These were masterminded by the government. ${ }^{21}$ It is estimated that the Darfur conflict resulted in a total of 400,000 deaths, 3 million internally displaced persons and over 200,000 refugees. ${ }^{22}$ The daunting question is what should happen to these atrocities? Should they go unpunished? The fact that some governments referred the situation in their countries to the ICC suggests that they needed the ICC's intervention. ${ }^{23}$

It should be noted that the governments have an obligation to bring perpetrators to justice. They may not be able to do so because of weak judicial bodies or complex political situations. In some cases, the governments may be unwilling to halt the atrocities and bring the culprit to accountability because they are the abusers. What should be done in these situations to stop and prevent these atrocities? The ICC provides the platform for that: by using the law to stop and prevent

18 See AU Summit Decision on the Meeting of African States Parties to the Rome Statute of the International Criminal Court (ICC), Assembly/AU/Dec 245(XIII), July 2009; See also D. Tladi, 'The African Union and the International Criminal Court: The Battle for the Soul of International Law', South African Year Book of International Law, Vol. 34, 2009, pp. 57-69 for detailed discussion of the AU's position on ICC's indictment of Al-Bashir.

19 Id.

20 See Address by Moreno-Ocampo, 2007.

21 L. Moreno-Ocampo, First Prosecutor of the International Criminal Court, keynote address at Yale University, 6 February 2009. Available at <www.icc-cpi.int/NR/rdonlyres/F04CB063-1C1E -463E-B8FB-5ECE076FB1E0/279792/090206_ProsecutorskeynoteaddressinYale.pdf〉.

22 Adar, 2010.

23 It should be noted that out of the eight cases under consideration, four were referrals from governments, two from the Security Council and two by virtue of the Prosecutor's investigation. 
atrocities. So it is not about the ICC chasing after Africans and African leaders per se, but rather dealing with hard situations to protect the rights of victims and prevent future occurrence of abuses in Africa and other parts of the world. It becomes political, however, when the alleged perpetrator happens to be the government, as in the case of Sudan and Kenya. It is imperative that African governments live up to their obligations to the ICC and take genuine steps to stop and prevent impunity on their shores within the law. The desirability of ICC's intervention in the African situation does not rule out the allegation of selective justice when the ICC overlooks similar situations elsewhere on the globe.

Second, the issue of selective justice should be examined in the light of international and domestic contexts of ICC's operations. The issue regarding selective justice in international contexts is whether similar events that triggered the ICC's intervention in African situations have occurred or are occurring elsewhere around the globe that the ICC has ignored or is ignoring while picking only on Africa. In that case one could allege selective justice. In a round-table discussion by some civil society organizations in Africa on 'The ICC and Africa', a key point that emerged was that similar situations that the ICC is pursuing have occurred or are occurring in Afghanistan, Georgia or Palestine but have been overlooked and Africa has become the ICC's "laboratory". ${ }^{24}$ Thus "the ICC's sharpest critics claim that international criminal law does not apply to the powerful, only the weak" ${ }^{25}$ A case study of analytical jurisprudence on conflict situations around the globe would be required on this matter.

As regards selective justice in domestic contexts, it should be discussed whether the ICC is selective in its indictments on a discriminatory basis, that is whether members of the same faction are indicted as opposed to members of other factions in situations where all factions were known to have committed abuses. As at now for all the referrals from government, the ICC ended up indicting anti-government forces, even though pro-government forces were alleged to have committed atrocities. In the situation in Cote d'Ivoire, for example, it is believed that atrocities were committed by both Alassane Outtara forces ${ }^{26}$ and Laurent Gbagbo forces but that only Gbagbo and his wife have been indicted. Likewise in Uganda, the claim is made that both sides to the conflict committed atrocities but those on the part of the government have not been indicted. Although the ICC Prosecutor has said that it has not completed its investigations in Uganda, it does not appear likely that government-related officials will be indicted. $^{27}$

T. McNamee, 'The ICC and Africa: Between Aspirations and Reality: Making International Justice Work Better for Africa', Reflections on a High-level Roundtable 18-19 March 2014, Addis Ababa, Ethiopia, co-hosted by The Brenthurst Foundation and the African Center for Strategic Studies. Brenthurst Discussion Paper 2, 2014.

25 Id., p. 6.

26 Human Rights Watch, Côte d'Ivoire: Ouattara Forces Kill, Rape Civilians During Offensive. Retrieved on 21 September 2014 from <www.hrw.org/news/2011/04/09/c-te-d-ivoire-ouattaraforces-kill-rape-civilians-during-offensive $>$.

27 Geis \& Mundt, 2009. 
Third, the allegation of selective justice should be discussed in terms of whether by considering the conglomerate of the international order some states are immune from the ICC's process or are not likely ever to be brought before the ICC. The claim of selective justice could be made under such circumstances, which would undermine the very essence of global justice. On the face of it, the ICC Statute could apply to any situation, because even if the state is not a party to the Rome Statute, the Security Council could refer a situation in a non-state party to the ICC and the ICC would exercise jurisdiction over such a matter. Legally and conceptually, no state is immune from the ICC's jurisdiction. However, as pointed out by McNamee, the "ICC's sharpest critics claim that it applies only to weaker states and not powerful states". This is inasmuch as "the major powers have become, in essence, both players and referees, formulating the rules of the game but refusing to play by them". ${ }^{28}$ The main reason is that out of the five permanent members of the UN Security Council, three, namely USA, China and Russia, are not members of the ICC Statute. In reality, they and their affiliates seemed far-fetched from the tentacles of the ICC. America, in particular, apart from not being a state party to the ICC, has also entered into an agreement with other states not to surrender American citizens to the ICC but to hand them over to America whenever the occasion arises. States are likely to comply with their treaty obligations to America because the ICC is enjoined not to make requests from states if compliance by such states with the ICC's request would jeopardize the states' treaty obligations to other states. ${ }^{29}$ The stands adopted by China, United States and Russia on the ICC undermine the very essence of the global criminal justice idea enshrined in the ICC Statute and send negative signals to Africa and the rest of the world that they and their affiliates are immune from the ICC. Meanwhile, they are members of the Security Council with the mandate to refer situations to the ICC for investigation and have done so, as already discussed. Again the United States is exercising global leadership to track the recalcitrant indictees of the ICC who are currently at large. This smacks of selective justice.

Another aspect of selective justice flowing from the above is that the state parties of the ICC make up $27 \%$ of the world population and $70 \%$, that is the majority, are outside its jurisdiction - India (1,27 billion), China (1,390 billion), Indonesia (230 million), Russia (150 million), Japan (125 million), USA (312 million). ${ }^{30}$ The ICC cannot claim to be exercising universal justice and for that matter being the criminal justice system for the new global or international order. In a typical criminal system everyone within the body polity is subject to the criminal proceedings as laid down by law. It is therefore necessary that the ICC intensifies its campaign to bring the current non-state parties on board.

\section{See McNamee, 2014.}

Art. 98(1) of the Rome Statute.

J.M. Mbaku, Africa's Case against the ICC. Paper for Panel discussion on "The International Criminal Court in Africa: Bias, Legitimate Objections, or Excuses for Impunity?" co-hosted by New York University's School of Continuing and Professional Studies (SCPS), Center for Global Affairs and the International Center for Transitional Justice (ICTJ). Retrieved on 21 June 2014 from < www.brookings.edu/blogs/africa-in-focus/posts/2014/03/13-international-criminal-court - mbaku>. 
The foregoing discussed the issue of selective justice in terms of whether (1) The crimes for which the ICC has intervened in the African situation are indeed covered by the Rome Statute, (2) whether such crimes are occurring elsewhere on the globe and the ICC has failed to intervene and whether it is discriminatory in its indictment against factions to the same conflict and (3) whether by the very conglomerate of international order vis-à-vis the ICC some countries around the globe are immune from the ICC even in the remotest test. It is clear that the ICC's intervention in African situations is justifiable since the situations involve commission of alleged crimes within the ICC's jurisdiction. However, the issue of selective justice cannot be dismissed if other countries work their way out of the jurisdiction of the ICC, as have the United States and other permanent members of the Security Council.

\subsection{The Indictment/Trial of Heads of States}

The other issue raised by the AU deals with the indictment/trial of heads of states. The AU has protested against the indictment of Al-Bashir the President of Sudan. He was the first sitting president to be indicted by the ICC. The Government of Sudan protested against Al-Bashir's indictment as being an affront to the sovereignty of Sudan. ${ }^{31}$ The AU issued a communiqué that they would not hand him over to the ICC, ${ }^{32}$ and asked member states not to cooperate in handing over Al-Bashir to the ICC. ${ }^{33}$ The ICC's request to some AU member states to arrest AlBashir but those member states did not comply with the request. ${ }^{34}$ The Arab League has also registered its disapproval of the indictment against Al-Bashir. ${ }^{35}$ The Arab League and the AU asked the Security Council to suspend the proceedings in favour of the ongoing efforts for peace in the Sudan region. These efforts to suspend the ICC activities did not succeed. ${ }^{36}$ In July 2009, the AU announced that it would not cooperate with the ICC in arresting Al-Bashir. ${ }^{37}$

Several issues have emanated from ICC's indictment and issuance of a warrant of arrest against Al-Bashir, head of state of Sudan. ${ }^{38}$ The first issue has to do with the personal immunity of Al-Bashir as head of state vis-à-vis the jurisdiction of the ICC, that is, whether heads of states are immune to the ICC's proceedings. Ordinarily, heads of states and certain categories of diplomatic officials enjoy

31 Jalloh et al., 2011.

32 Nkansah, 2011; Tladi, 2009.

33 Jalloh et al., 2011.

34 Barnes, 2011 gives instances of Kenya's and Chad's refusal to honour the arrest warrant requesting them to arrest Al-Bashir's.

35 See D. Akande, 'The Legal Nature of Security Council Referrals to the ICC and Its Impact on Al Bashir's Immunities', Journal of International Criminal Justice, Vol. 7, 2009, pp. 333-352.

36 See Jalloh et al., 2011.

37 Communique of the 175th Meeting of the Peace and Security Council of the African Union PSC/ PR/Comm9CLXXV; Communiqué of the 151st Meeting of the Peace and Security Council of the African Union (PSC/MIN/Comm1(CLI).

38 See Jalloh et al., 2011; Akande, 2009, pp. 334-335; Barnes, 2011; Ssenyonjo, 2009, p. 397, where the authors discuss issues of the immunity of heads of state with regard to the ICC; P. Gaeta, 'Does President Al Bashir Enjoy Immunity from Arrest?', Journal of International Criminal Justice, Vol. 7, 2009, pp. 315-332. 
immunity by virtue of customary international law or based on treaty. This includes immunity from arrest. The ICC Statute, however, provides in Article 27 (1) that one's position as head of state would not immunize him from criminal responsibility under the Rome Statute. Further, Article 27(2) of the Rome Statute provides that a person's "immunity or procedural rules" under national legal systems would not prevent the ICC from exercising jurisdiction over him. Thus, when states signed up to the ICC, they agreed to the removal of the immunity of the head of state with regard to the ICC's jurisdiction. ${ }^{39}$ In consequence, the indictment of the heads of states of state parties to the Rome Statute is within the bounds of the ICC.

The second issue has to do with the ICC's indictments of a head of state of a non-state party such as Al-Bashir and Libyan officials even though Sudan and Libya are not parties to the Rome Statute and thereby have not waived the immunity of their officials. It should be pointed out that the ICC exercises jurisdiction over nationals of non-state parties through a referral by the UN Security Council by virtue of Chapter VII of the UN Charter. ${ }^{40}$ By implication, if a state does not sign up to the ICC or enter into a cooperation agreement with it, and the Security Council referred the matter to it, the ICC can exercise jurisdiction over that state. And the referral removes any immunity that may exist. There is a general consensus among scholars on this. ${ }^{41}$

The third issue that has been raised by scholars and commentators is whether states that are not party to the ICC, such as Sudan and Libya, which have been referred to the ICC by the Security Council, can be arrested by other state parties and be dragged before the ICC ${ }^{42}$ This issue has been raised due to the Pre-Trial Chamber's decision in The Prosecutor v. Al Bashir, ${ }^{43}$ where the Pre-Trial Chamber gave a decision on the application by the Prosecutor for the issuance of an arrest warrant against Al-Bashir. In its decision, the Pre-Trial Chamber gave a directive to the Registrar to prepare and circulate a request for cooperation for the arrest and surrender of Al-Bashir to the appropriate Sudanese authorities, state parties to the ICC Statute and all UN Security Council members that are not parties to the ICC Statute. ${ }^{44}$

With regard to this decision under consideration, Akande ${ }^{45}$ argues that because the case of Al-Bashir was a referral from the Security Council resolution,

39 Akande, 2009, pp. 334-335.

40 Art. 13(b) of the Rome Statute

41 Akande, 2009; A. Derbal, 'The ICC's Involvement in the Situation in Darfur: Not a Threat to Peace', University of Notre Dame, Center for Civil and Human Rights, Working Paper No. 1 Winter 2008; D. Terzian, 'Personal Immunity and President Omar Al Bashir: An Analysis under Customary International Law and Security Council Resolution 1593', UCLA Journal of International Law and Foreign Affairs, Vol. 16, 2011, p. 279. Available at SSRN: <http://ssrn. com/abstract= 1969195>; Gaeta, 2009; Ssenyonjo, 2009.

42 Akande, 2009, pp. 334-335; Gaeta, 2009.

43 The Prosecutor v. Al Bashir, Decision on the Prosecution's Application for a Warrant of Arrest against Omar Hassan Ahmad Al Bashir, ICC-02/05-01/09 Pre-Trial Chamber 1, 4 March 2009 (hereinafter Prosecutor v. Al Bashir).

45 Akande, 2009, pp. 334-335. 
it removed the immunity, so Sudan is clearly under an international obligation to arrest Al-Bashir. Terzian ${ }^{46}$ was of the view that the ICC had the jurisdiction to indict and arrest Al-Bashir because his personal immunity was removed by the Security Council's referral to the ICC. He affirmed, however, that all heads of states possess inviolate personal immunity at international law but that in regard to Al-Bashir it was specifically removed by Security Council Resolution 1593, which referred the Darfur case to the ICC. In the said Resolution the Security Council made it clear that personal immunities did not exist for purposes of Article 98(1). Article 98(1) prohibits the ICC from making requests from states if the request would make the state "act inconsistently with its obligation under international law with respect to the State or diplomatic immunity of a person or property of a third State, unless the court can first obtain the cooperation of that third state for the waiver of the immunity". In any case the International Court of Justice has held, in what has come to be known as the Arrest Warrant Case, that heads of state are not immune from arrest by an international criminal court like the International Criminal Tribunal for Rwanda or the International Criminal Tribunal for former Yugoslavia. ${ }^{4}$

Gaeta, on the other hand, argues that the warrant of arrest to ICC state parties does not in itself breach international law. However, states are not obliged to comply with the request to arrest and hand over Al-Bashir since the request is "patently at odds" with Article 98(1) of the Statute. Gaeta further maintained that any state other than Sudan risks breaching the international rules on the "immunity from arrest for incumbent heads of state". ${ }^{48}$

The foregoing debate notwithstanding, it is being submitted that the Rome Statute is emphatic on this matter and seems to have addressed it by Article 98. The ICC will have to target those states that do not have treaty obligations with Sudan, or get those states to waive their obligations to Sudan. This aside, could customary international law and, for that matter, state obligations to other states on diplomatic immunity be waived by states under any obligations at all?

The law aside, the practical effectiveness of indicting a head of state that happens to be uncooperative like Al-Bashir comes to the fore. This boils down to whether an arrest warrant against heads of states will be honoured by the country of a given head of state. This is critical when the head of state enjoys immunity at the national levels, and therefore indictment of a head of state by an international body would contradict the national immunity enjoyed by the head of state. This is likely to be explained away in terms of a country's international obligation superseding its domestic policy, but it is not as simplistic as that. It should be noted that in typical constitutional democracies, heads of states are subject to the law and could be impeached and removed from office. However, they enjoy immunity for actions and omissions whilst in office. For example in Ghana, the

46 D. Terzian, 'Personal Immunity and President Omar Al Bashir: An Analysis under Customary International Law and Security Council Resolution 1593', UCLA Journal of International Law and Foreign Affairs, Vol. 16, 2011, p. 279. Available at SSRN: 〈http://ssrn.com/abstract=1969195>.

47 As cited in Gaeta, 2009.

48 Id. 
President is immune from liability for acts or omissions done or purported to have been done by him in the exercise of his functions "under the Constitution or any other law". ${ }^{49}$ However, the President's actions and omissions which bother on constitutional infractions human rights violations can be challenged in court. ${ }^{50}$ But such actions are to be instituted against the Attorney-General and not the President. ${ }^{51}$ In this sense the ICC's indictment may contradict a national law where the acts and omissions in question have been undertaken by the head of state in the course of work as an executive head of state. As regards private acts and omissions, some countries such as Ghana grant their heads of state procedural immunity so that they cannot be sued while in office but after leaving office. ${ }^{52}$ Others such as the United States do not grant procedural immunity for the private acts and omissions of the sitting president, and hence a civil suit may be instituted against the president while in office. ${ }^{53}$

An argument the foregoing is likely to generate is that a country has an obligation to hand over their head of state to the ICC in total violation of their laws. And that such affected countries should harmonize their laws with the Rome Statute in compliance with their obligations under the Statute where presidential immunity is concerned particularly where they happen to be a dualist state. But this may require a constitutional reform which could involve a referendum where presidential immunity happens to be an entrenched constitutional provision. It has serious political and economic implications and more so for non ICC member states. But more importantly should a non ICC state member which has been dragged before ICC by the Security Council be saddled with such an obligation that it never signed up for?

Again it should be noted that as head of state, Al-Bashir controls the national apparatus that has to arrest him, so it is not likely that Sudan can arrest and hand him over to the ICC. The ICC would have to depend on other countries for assistance in implementing the arrest warrant. But here too cooperation is unlikely. The evidence so far shows that state parties are reluctant to arrest a sitting president. Thus, the arrest warrant to state parties against Al-Bashir has not been honoured. ${ }^{54}$ When Charles Taylor was indicted by the Special Court for Sierra Leone, it could not get cooperation from countries to arrest him as President of Liberia immediately. Charles Taylor was handed over to the Special Court after he ceased to be president and a new elected government had been established in Liberia. ${ }^{55}$

49 Art. 57(4) of Constitution of Ghana, 1992.

50 See Arts. 2, 57(4) and 130 of the Constitution of Ghana, 1992.

51 See Art. 88(5) of the 1992 Constitution of Ghana; Amidu v. President Kuffour [2001-2002] SCGLR 86; New Patriotic Party v. President Rawlings [1993-1994] 2 GLR 193.

52 See Art. 57(5) and (6) of the 1992 Constitution of Ghana.

53 See Mississippi v. Johnson, 4 Wall, 475 (1867); Clinton v. Jones, 520 U.S. 681 (1997); see also L. Epstein \& T.G. Walker, 2009. Constitutional Law for a Changing America (4th Ed). Washington, D.C.: CQPress, A division of Sage (2009).

54 Barnes, 2011.

55 Geis \& Mundt, 2009; P. Hayner, 'Negotiating Peace in Liberia: Preserving the Possibility for Justice', Centre for Humanitarian Dialogue and International Center for Transitional Justice Report, 2007. 
This suggests that the ICC needs to pay attention in its operations to the domestic contexts of its interventions in order to be effective.

The indictment/trial of Uhuru Muigai Kenyatta and William Samoei Ruto, Kenyan President and Vice President respectively, presents some dynamics. The situation in the Republic of Kenyan before the ICC was by virtue of the Prosecutor's investigation. On 27 December 2007, a general election was held in Kenya. The incumbent President, Mwai Kibaki, who represented the Party of National Unity and Raila Odinga from the Orange Democratic Movement were the leading candidates. The results announced by the Electoral Commission of Kenya showed that Kibaki had been re-elected and he was sworn in as President. Immediately after the Electoral Commission's announcement, Odinga rejected the result, claiming that widespread electoral fraud had taken place. ${ }^{56}$ In the days that followed violence spread throughout the country. An estimated 1,200 people died and more than 500,000 were displaced from their homes. A peace deal was brokered through the mediation of former United Nations Secretary General Kofi Annan whereby Kibaki would remain as President and Odinga would take over the newly created office of the Prime Minister.

The Coalition government established the Commission of Inquiry into the Post-Election Violence (CIPEV). The CIPEV found that massive violence had taken place and recommended for the establishment of a hybrid tribunal to prosecute the perpetrators of the violence. Alternatively, the list of alleged perpetrators which had been given to Kofi Annan in confidence should be given to the ICC. A bill placed before the Kenyan Parliament for the establishment of the Court failed twice. ${ }^{57}$ In November 2009, the ICC prosecutor announced that he would request permission from the ICC to start an investigation into crimes against humanity committed after the disputed election. This was the first time that the prosecutor decided to investigate a case on his own authority. On 31 March 2010, the ICC authorized the prosecutor to open formal criminal investigations into the political leaders who organized the violence. ${ }^{58}$ In 2010 , the Prosecutor announced that he was seeking summonses for six people ${ }^{59}$ and eventually indicted three people including Uhuru Muigai Kenyatta and William Samoei Ruto. 60

56 Global Policy Forum, 'International Criminal Court Investigations Kenya', Retrieved on 10 March, 2014 from <www.globalpolicy.org/international-justice/the-international-criminalcourt/icc-investigations/kenya.html>.

57 C. Jalloh, 'International Decision: Situation in the Republic of Kenya No. ICC-01/09-19. Decision on the Authorization of an Investigation', The American Journal of International Law, 2009, Vol. 105, pp. 540-547.

58 Global Policy Forum, 'International Criminal Court Investigations Kenya', retrieved on 10 March 2014 from <www. globalpolicy. org/international-justice/ the -international-criminal-court/iccinvestigations/kenya.html $>$.

59 The six people were: Deputy Prime Minister Uhuru Kenyatta, Industrialisation Minister Henry Kosgey, Education Minister William Ruto, Cabinet Secretary Francis Muthaura, radio executive - Joshua Arap Sang and former police commissioner Mohammed Hussein Ali - all accused of crimes against humanity.

60 Retrieved on 20 October 2014 from <www.icccpi.int/en_menus/icc/situations\%20and\%20cases/ situations/situation\%20icc\%200109/Pages/situation\%20index.aspx >. 
In spite of ICC's indictments, Uhuru Muigai Kenyatta and William Samoei Ruto, contested the general election in Kenya in 2013 and became President and Vice President. AU considered ICC's proceedings against the Kenya's President and his Deputy as unprecedented and abuse of universal justice. Hence, asked Kenya to request the Security Council for a deferral in "conformity with Article 16 of the Rome Statute that would be endorsed by all African State Parties" ${ }^{61}$ Nevertheless, the proposed resolution by Kenya and a few other African States to the Security Council to defer the trial of Uhuru Muigai Kenyatta and William Samoei until they finish their term in office failed. ${ }^{62}$ It appears, however, that the Kenyan people want the trial of their leaders to go on so they could clear their names.

Tying everything together, it should be pointed out that the AU's position on the indictment/trial of the heads of state under consideration is not that the indictments against Al-Bashir, President of Sudan, and the proceedings against Uhuru Muigai Kenyatta and William Samoei Ruto, President and Vice President of Kenya, be dropped. But that they should be suspended until they complete their term of office. ${ }^{63}$ In a sense the AU is seeking temporary procedural immunity for them. Thus, the request of Kenya and some African countries does not amount to seeking removal of the ICC's jurisdiction over these heads of states. It may be concluded that the AU's position is not in breach of Article 27, which is on jurisdiction and is consistent with the norms of international and national legal systems.

It should be pointed out that ICC proceedings against heads of states could give rise to constitutional and political implications for the country involved. These may include the arrest and detention and or conviction and imprisonment of a head of state. Any of these happenings would mean the physical absence of the head of state from the country. How then will the head of state govern his/ her country? Would he or she be administering the country from detention or prison? How should the affected country deal with it? Should the person be removed from office by the country involved? What if the ICC's proceedings against him or her do not constitute grounds for removal by the law of the country involved? What happens to the people's franchise? Why should any entity have the authority to cause the absence of the head of state who has been duly elected by the people of his country in breach of the people's rights. Even the trial of Uhuru Muigai Kenyatta and William Samoei Ruto had political implications. Whenever they have to travel to The Hague to attend court as leaders of state they go with the necessary courtesies which could be at the expense of the country including time. It should also be noted that as African countries are emerging democracies with developmental problems to confront, the energies of heads of

61 See Extraordinary Session of the Assembly of the African Union, 12 October 2013, Addis Ababa, Ethiopia, Decision on Africa's Relationship with the International Criminal Court (ICC), Ext/ Assembly/AU/Dec. 1 (October 2013). Para. Ix.

62 See Security Council SC/11176, 15 November 2013. Retrieved on 20 July 2014 from <www. un. org/News/Press/docs/2013/sc11176.doc.htm>.

63 See Extraordinary Session of the Assembly of the African Union, 12 October 2013, Addis Ababa, Ethiopia, Decision on Africa's Relationship with the International Criminal Court (ICC), Ext/ Assembly/AU/Dec. 1 (October 2013). 
states in Africa especially are needed for the proper functioning of their duties of office and for governance. Their energies should not be diverted by the ICC. Deferring proceedings against the heads of states under consideration will ease tensions and make room for effective governance especially for Kenya that is dealing with a serious problem of terrorism with their President and Vice President before the ICC. After all the crimes of the Rome Statute are not statute barred. For these reasons the Security Council should not see its role merely as advancing international law. It is also about dealing with a people, a community and a nation seeking development and stability.

\section{Contextualizing ICC's Operations}

Apart from the politics and the refusal or failure of African States Parties to cooperate with the ICC or to comply with their obligations under the Rome Statute, and the stands of the AU, the impasse also stems from the failure of the ICC to pay attention to the local contexts and its failure to harmonize its operations in the places of its intervention. The Prosecutor of ICC, however, maintained that any consideration given to the local situation would undermine the Court. He observed thus:

For each situation in which the ICC is exercising jurisdiction, we can hear voices challenging judicial decisions, their timing, their timeliness, asking the Prosecution to use its discretionary powers to adjust to the situations on the ground, officials of State Parties calling for amnesties, the granting of immunities and other ways to avoid the prosecutions, supposedly in the name of peace; we can hear voices portraying the ICC as an impediment to progressing further with Peace processes. These proposals are not consistent with the Rome Statute. They undermine the laws State Parties committed to....there can be no political compromise on legality and accountability. ${ }^{64}$

But the Rome Statute that state parties committed to impliedly makes room for the ICC to adjust its operations to the situation on the ground. ${ }^{65}$ To begin with, the ICC is to play a complementary role to 'national criminal jurisdictions'. By Article 17(1), (a) (b) (c), it can exercise this complementary role to investigate or prosecute a matter where a State that has jurisdiction over a matter "is unwilling or unable genuinely to carry on with investigation or prosecution", or after investigating is unwilling or unable to prosecute a matter that has been tried by a trial by State in order to shield the perpetrator from the ICC, and where the State trial was not impartial. By Article 98(1) the ICC is to refrain from making a demand from any State that would jeopardize that State's obligation under international law. 
Further, Article 53(1)(c) provides that the Prosecutor should not initiate investigation into any matter where, considering "the gravity of the crime and the interest of the victims, there is nonetheless substantial reason to believe that an investigation would not serve the interest of justice". The "interest of justice" has become a subject of contention among legal scholars and commentators as they proffer a variety of interpretations. The bone of contention is whether it should be interpreted in such a manner as to make room for domestic consideration. Whereas some scholars have called for strict interpretation, others have advocated a more liberal interpretation. But, really, what is the essence of Article 53? There has been speculation that the ambiguity of Article 53 is intentional because states could not agree during the negotiations on whether to allow amnesty to prevail in the face of the international criminal jurisdiction of the ICC. In view of the exigencies of extreme political situations that may warrant an amnesty, they provided for Article 53 by which the ICC could defer to national amnesties. ${ }^{66}$ Certainly Article 53 would be subjected to the Vienna Convention on the Law of Treaties (VCLT) for interpretation. Kourabas, for instance, has used the VCLT framework to offer an interpretation to oust amnesty considerations. ${ }^{67}$

Article 53 gives the Prosecutor discretionary power to initiate or decline investigation into an issue. The exercise of discretion is to a large extent informed by the perceived role of the ICC by its mandate. The controversy is aptly raised by Serge Brammetz, Deputy Prosecutor of the ICC, as to "whether the ICC is a political system with judicial tools or a judicial system surrounded by a political reality" ${ }^{68}$ The Prosecutor, however, made it clear that his office has been given the legal mandate to prosecute and punish and nothing else, so his office shall not be hindered by any domestic considerations. In an interview conducted by E. Blumenson with Serge Brammetz, the ICC Deputy Prosecutor, Brammetz, maintained that the ICC is purely a judicial tool that should not meddle with issues on peace and stability. ${ }^{69}$ Brammetz stated that the ICC "is here for justice not politics [...] The priority of the Rome Statute is to prosecute [;] it's not to provide political stability" ${ }^{70}$ In this sense the ICC sees itself as a court with judicial functions and not a political institution to involve itself with issues about peace and stability. It has been suggested that it does not have the capacity to engage in political issues and that any attempt to do so will dissipate its resources and und ermine its integrity. Blumenson maintained that "[I]f the ICC also finds a prosecution too costly to pursue based on these same pressures, it would merely be replicating the problem the ICC was created to solve". ${ }^{1}$

See E. Blumenson, 'The Challenge to a Global Standard of Justice', Columbia Journal of Transnational Law, Vol. 44, No. 801, 2006, pp. 801-874; M. Kourabas, 'A Vienna Convention Interpretation of the "Interest of Justice" Provision of the Rome Statute, the Legality of Domestic Amnesty Agreements, and the Situation in Northern Uganda: “A Great Qualitative Step Forward" or Normative Retreat?', U.C. Davis Journal of International Law and Policy, Vol. 14, 2007, p. 59.

67 Kourabas, 2007.

68 Quoted in Blumenson, 2006, p. 821.

69 Id.

70 Id.

71 Id. 
The debate is ongoing. But it is being proposed that any proffered interpretation on the 'interest of justice' should take the domestic contexts into consideration for (1) ICC's own efficacy and (2) the interest of society concerned in terms of peace and stability. But if and only if the ICC could appreciate the overall goal of justice intervention in a traumatized society or after a violent conflict as part of the measures, then it would be possible to contextualize its operations and take the local dynamics into consideration. The Prosecutor actually recognized the divergent needs of such traumatized societies when he remarked on the effect of domestic contexts on their operations thus:

How to ensure the enforcement of the Court's decision? How to ensure in particular, the arrest and surrender of individuals sought by the Court? How to ensure the enforcement of the Court's decisions in situation where the international community is simultaneously trying to achieve many objectives; for instance, establishing security, providing humanitarian assistance, promoting political dialogue between the parties to the conflict, and preparing for reconstruction and development. ${ }^{72}$

It should be pointed that these countries were ravaged or are being ravaged by civil wars or complex political upheavals. Their primary concern, as argued somewhere, is or should be the attainment of peace and stability. In view of this, the pursuit of international criminal justice through the ICC framework in these wartorn countries is not or should not be an end in itself, but a tool or a strategy to facilitate peace-building, as argued elsewhere. ${ }^{73}$ In this sense, the domestic context that the ICC confronts or is likely to confront, namely the political contexts, existing amnesties, existing juridical processes as well as the sociocultural conditions, are critical to its effectiveness as well as to facilitating the overall objectives of peace-building in the countries of their intervention, as shown in the following section.

\subsection{Putting the ICC in the Domestic Contexts of Its Operation}

\subsubsection{The Political Contexts}

The political contexts of ICC's intervention are critical to its effectiveness by getting the indictees and also ensuring that its intervention supports the countries involved and does not aggravate the already fragile situation. As far as the political situation is concerned, a major problem the ICC confronts in its interventions is situations of ongoing conflict and situations where the indictees have the upper hand or have not been subdued. It becomes difficult to get the indictees to submit to the ICC. The indictees also intensified the perpetration of atrocities in reaction to the ICC's intervention, as witnessed in Uganda and Sudan. ${ }^{74}$ 
In Uganda, a conflict broke out between the Government of Uganda and the Lord's Resistance Army (LRA), a rebel insurgency group in Northern Uganda. For over 20 years the Ugandan government could not quell the insurgency, in which massive human rights abuses occurred with untold suffering to the civilian population of Northern Uganda. In December 2003 during the conflict, the Ugandan government invited the ICC to carry out an investigation and prosecute those responsible for the atrocities being committed. The ICC carried out the investigation, which resulted in the indictment of five LRA Commanders in 2005. The government could not subdue them and could not arrest and hand them over to the ICC. Meanwhile, the situation on the ground was aggravated because the LRA intensified the atrocities against the defenceless civilians. While the warrants of arrest subsisted, the government entered into negotiation with the LRA in July 2006 to settle the conflict and grant them amnesty. The prosecution maintained that his office would not drop the indictment. ${ }^{75}$ The indictees are currently at large. Similarly, the indictment of Al-Bashir, the President of Sudan, by the ICC is met with certain hitches. Al-Bashir has refused to submit to the ICC. The member states have also failed to respect the warrant of arrest issued by the ICC for his arrest. The indictment of Al-Bashir worsened the already fragile situation in Darfur, Sudan. The effect of this is that the indictees are at large. And the countries involved were further traumatized. ${ }^{76}$

The situations above evoke the ideology that one cannot sit in judgment over those that one has not conquered or subdued. The Allied Forces were able to establish the Nuremberg and Tokyo Tribunals to try war crimes because they had defeated Germany. The conflict in Sierra Leone had continued without any of the warring factions emerging a winner. The Revolutionary United Front (RUF) and the government negotiated an end to the conflict when neither could win it and agreed to have the Truth and Reconciliation Commission ( TRC) as accountability as compromises were made without prosecutions. But the moment the government subdued the RUF, it pushed for prosecutions, which culminated in the establishment of the Special Court for Sierra Leone. In Cote d'Ivoire, Alassane Quattara collaborated with the ICC to indict Laurent Gbagbo and his wife after Gbagbo and his supporters had been subdued.

In a typical criminal justice system, countries possess coercive powers with the necessary enforcement machinery to drag culprits before the law, except in a few situations where they have to rely on other countries to extradite fugitives to face the law in the respective countries. But the emerging global governance and justice system with the ICC being the global criminal justice system does not have the apparatus to enforce its arrest warrants and other orders and depends on cooperation from state parties. ${ }^{77}$ Until a system is put in place by the ICC to pursue and capture or drag indictees before the ICC from wherever they may be, mission and Special Court for Sierra Leone', Legon Journal of International Affairs, Vol. 6, No. 1, 2009, pp. 27-44.

76 Nkansah, 2011.

77 See Barnes, 2011, where the impasse between the AU and Africa is discussed in detail. 
domestic political exigencies cannot be ignored in the pursuit of justice by the ICC in certain situations. This position is supported by several authors; politically, how a conflict or repressive regime ends is a critical factor in influencing the choice of accountability mechanism, and how emerging democracies choose to deal with past abuses is determined by the balance of power between the incumbent and the outgoing regimes. ${ }^{78}$

\subsubsection{Existing Amnesties}

The ICC in its interventions is likely to be confronted with amnesties. Amnesty refers to "the legal tools deployed by governments to remove criminal and/or civil sanctions from specified categories of offenders or offences". ${ }^{79}$ It has been used by rulers to deal with human rights abuses since time immemorial. ${ }^{80}$ Blumenson points out that amnesty sometimes "has been declared to achieve legitimate goals the country deems of overriding importance, such as peace, truth, or reconciliation; sometimes its sole purpose is impunity" ${ }^{81}$ It comes in several forms: leniency in punishment, conditional or unconditional amnesties. The form of amnesty determines whether prosecution could be permitted at all. ${ }^{82}$ The granting of amnesty has become an issue among human rights activists, jurists, scholars and commentators who criticize governments for the grant of amnesty for heinous international crimes. Sadat maintains that amnesties given at gunpoint, as was done in Sierra Leone and the former Yugoslavia do not result in peace "but

78 N. Doyle, Chile's Process of Recovery from Human Rights Violence: Evaluating Restorative and Retributive Approaches (master's thesis on file at Dalhousie University, Halifax, Nova Scotia, 2004); J.G. Gibson, 'Truth, Justice and Reconciliation: Judging the Fairness of Amnesty in South Africa', American Journal of Political Science, Vol. 46, No. 3, 2002, pp. 540-556; L.S. Graybill, 'Pardon, Punishment, and Amnesia: Three African Postconflict Methods', Third World Quarterly, Vol. 25, No. 6, 2004, pp. 117-1130; K.C. Moghalu, 'Prosecute or Pardon? Between Truth Commissions and War Crimes Trials', in C.L. Sriram \& S. Pillay (Eds.), Peace versus Justice? The Dilemma of Transitional Justice in Africa, University of KwaZulu-Natal Press, South Africa, 2009, pp. 69-95; D. Tutu, No Future Without Forgiveness. Johannesburg: Ride, 1999; E. Skaar, 'Truth Commissions, Trials - or Nothing? Policy Options in Democratic Transitions', Third World Quarterly, Vol. 20, No. 6, 1999, pp. 1109-1128; J.D. Tepperman, 'Truth and Consequences', Foreign Affairs, Vol. 81, No. 2, 2002, pp. 128-145; J.D. Rae, Hello malae, Goodbye barang: Building Peace, Justice, and Reconciliation in Post-conflict Cambodia and East Timor (doctoral dissertation on file at University of Hawai'i, Manoa, 2005); P. van Zyl, 'Dilemmas of Transitional Justice: The Case of South Africa's Truth and Reconciliation Commission', Journal of International Affairs, Vol. 52, No. 2, 1999, pp. 648-669; W. Verwoed, 'Individual and/or Social Justice after Apartheid? The South African Truth and Reconciliation Commission', European Journal of Development Research, Vol. 11, No. 2, 1999, pp. 115-141; L. Vinjamuri \& J. Snyder, 'Advocacy and Scholarship in the Study of International War Crime Tribunals and Transitional Justice', Annual Review of Political Science, Vol. 7, No. 1, 2004, pp. 345-362.

79 L. Mallinder, 'Building Peace in Post-conflict Situations' (British Institute of International and Comparative Law, September 2011), Transitional Justice Institute, University of Ulster, Research Paper No. 11-06, p. 3.

80 See Mallinder, 2011, p. 2.

81 Blumenson, 2006, p. 803.

82 Id., pp. 3-4. 
create temporary lull in the fighting" ${ }^{83}$ Even though amnesty has been criticized for aiding impunity and perpetration of abuses, ${ }^{84}$ it became a major legal tool in societies that were transitioning from authoritarian regimes to democracy, and likewise in societies emerging from wars. This is because the 'pursuit of justice' dichotomy has not been without hitches as the realities on the ground did not allow for retributive justice upfront in some transitional societies that had to resort to restorative justice for peace-building. ${ }^{85,86}$ This led to the 'peace versus justice dichotomy', ${ }^{87}$ that is, a trade-off of justice for peace. Blumenson argued that under certain circumstances conditional amnesties are morally acceptable. ${ }^{88}$

Amnesty was granted as part of the bargaining package in Sierra Leone to end the civil war. ${ }^{89}$ It would have been impossible to advance the peace process if there had been an insistence at the outset on justice by trials. The question of justice came to the fore after the government emerged victorious over the RUF. ${ }^{90}$ South Africa had to grant conditional amnesty to bring about the end of apartheid. ${ }^{91}$ This is because the agreement/arrangement, which ushered in the democratic government from apartheid, was a negotiated settlement between the ANC and the apartheid government. The ANC nationalist movement had both internal and external support, yet could not defeat the apartheid regime through its military campaigns. Similarly, the apartheid government realized it could not continue to ignore the quest for a democratic government. As a result, there was a need to accommodate each other. Conditional amnesty was therefore granted as a middle way to accommodate the old and the new regimes, and a truth commission emerged. In Chile, the new government that succeeded the Pinochet authoritarian regime could not adopt a policy to prosecute perpetrators of human rights abuses because Pinochet, the authoritarian leader, remained the head of the military after the demise of his rule. The Chile Legislature enacted amnesty laws absolving their officers from any acts or omissions. In short, the exigencies of the times made room for amnesty.

However, there is a reversal of the toleration of amnesty in the jurisprudence and practice of international justice in recent times. ${ }^{92}$ In a number of cases, the Inter-American Commission on Human Rights (IACHR) ruled that amnesty laws

See L.N. Sadat, 'Exile, Amnesty and International Law', Washington University in St. Louis School of Law, Faculty Working Paper Series, Paper No. 05-04-03, April 2005, p. 9; See also Blumenson, 2006; L. Mallinder, 'Amnesties in International Criminal Law', in W.A. Schabas \& N. Bernaz (Eds.), The Handbook of International Criminal Law, Routledge, New York, 2009.

84 Id., p. 9.

85 See Apori-Nkansah, 2009; See also Blumenson, 2006.

$86 I d$, p. 9.

87 See Sadat, 2005.

88 See Blumenson, 2006

89 See Peace Agreement Between the Government of Sierra Leone and the Revolutionary United Front of Sierra Leone, 1999. Retrieved on 20 February 2006 from <www. sierra -leone. org/ lomeaccord.html>.

90 Apori-Nkansah, 2009.

91 Van Zyl, 1999.

92 See Mallinder, 2009 for detailed analyses on the international courts' jurisprudence on amnesties. 
were in violation of State obligations to punish certain crimes that occur on their shores. In determining the validity of national amnesty laws in relation to a state's obligation to address impunity, the IACHR has in a number of cases, namely Ellacuría \& others v. El Salvador, ${ }^{93}$ Espinoza v. Chile, ${ }^{94}$ Hector Perez Salazar v. Peru, ${ }^{95}$ Gelman v. Uruguay ${ }^{96}$ and Arges Sequeira Mangas v. Nicaragua, ${ }^{97}$ ruled that amnesty laws that barred victims from pursuing judicial redress for violations suffered amount to a breach of the state's obligation to protect those rights.

In Espinoza v. Chile (1999), for example, the de facto Government of Chile decreed an amnesty law in 1978 in connection with the political repression that took place in that country from 1973 to 1978. Soria was kidnapped and killed. In July 1976, Soria's body was found in a canal in Santiago. The family of Soria instituted an action in the Supreme Court of Chile for the death of Soria. The Chilean Supreme Court found that state agents kidnapped, tortured and executed Soria. Yet the Chilean Supreme Court held that the amnesty law was valid and closed the case. It should be pointed out that earlier on the family had rejected the reparation award by the national reconciliation process in connection with the death of Soria. The family had also refused significant additional financial and moral reparations offered them by the Chilean government. In a subsequent action before the IACHR, the IACHR held that the position of the Chilean Court amounted to a breach of Chile's legal obligation and responsibility to protect human rights under the American Convention. This is because it foreclosed the possibility of Soria's arbitrary death being ever prosecuted. The IACHR reiterated that the overall input of the treaty obligation meant that national reconciliation endeavours should not constitute a bar to judicial remedy for victims. This is because the right to remedy includes judicial remedy and is not limited to compensation and official acknowledgment of responsibility for violations. Nevertheless, since the crimes under consideration fell within the realm of universal jurisdiction, perpetrators would be prosecuted in any event even if outside Chile. The Legislatures of Argentina and Chile have repealed the amnesty laws. ${ }^{98}$

In Prosecutor v. Kallon and Others ${ }^{99}$ the Defence Counsel argued that the Government of Sierra Leone is bound to observe the amnesty granted under Article IX of the Peace Agreement between the Government and the Revolutionary United Front of Sierra Leone (Lome Agreement) and that the Special Court should not assert jurisdiction over crimes committed prior to July 1999 when an

93 Ignacio Ellacuría and others v. El Salvador, Case 10.488 inter-Am.C.H.R No. 136/99. Retrieved on 7 November 2005 from <www.derechos.org/nizkor/salvador/doc/jesuits.html>.

94 Carmelo Soria Espinoza v. Chile, Case No. 11.725, inter-Am.C.H.R., No. 133/99 (1999). Retrieved on 7 November 2005 from <www.cidh.oas.org/annualrep/99eng/Merits/Chile11.725.htm>.

95 Hector Perez Salazar v. Peru, Case 10.562, Report No. 43/97. Retrieved on 17 February 2014 from <www1.umn.edu/humanrts/cases/1997/peru43-97.html>.

96 Gelman v. Uruguay, Inter-Am. Ct. H. R. (Ser.C.) No. 221(2011) available at <www.corteidh.or.cr/ docs/casos/articulos/seriec_221_ing.pdf>.

97 Arges Sequeira Mangas v. Nicaragua, Case 11.218, Report No. 52/97, Inter-Am. C. H. R. Retrieved on 17 February 2014 from <www1.umn.edu/humanrts/cases/1997/nicaragua52-97b.html>.

98 See Sadat, 2005, pp. 4-5.

99 Prosecutor v. Kallon and Others Case No. SCSL -2004-25-AR72 (E). Retrieved on 22 September 2014 from <www.transcrim.org/07\%20SCSL\%20-\%202004\%20-\%20Kallon\%20Kamara〉. 
amnesty was granted by virtue of the Lome Agreement. Further, it would be an abuse of process to allow the prosecution of any of the alleged crimes predating the Lome Agreement. The Special Court for Sierra Leone held that the amnesty granted by the Government of Sierra Leone cannot be interpreted as covering violations of international humanitarian law. The Lome amnesty was a domestic amnesty. As Article IX of the Lome Agreement addressed and could have legal force in respect of the national legal system of Sierra Leone only, the amnesty does not legally circumscribe the jurisdiction of the Special Court that has been established outside the national system. Any amnesty that encompasses crimes against humanity, serious war crimes, genocide or torture would be of doubtful validity under international law. In his analysis of the Special Court's decision in Prosecutor v. Kallon and Others on amnesty, Schabas concluded inter alia:

The problem with the conclusions of the Special Court on the issue of amnesty is that they are too absolute. They most certainly go beyond existing law ... Their effect, for example, is to condemn not only the peacemakers at Lomé but also a process in South Africa that was supervised by such noble souls as Nelson Mandela and Desmond Tutu. The Special Court is, of course, quite correct to note that a grant of amnesty under one jurisdictional regime cannot deprive another of the authority to prosecute where universal jurisdiction exists [...] But in declaring that Sierra Leone actually violated customary international law by granting the amnesty, the Special Court attempted to establish a principle that applies to all armed conflicts to the effect that peace cannot be bargained for amnesty. Ever. The corollary of such a claim can only be the assertion that war should continue, even where combatants are prepared to lay down their arms in return for an assurance that they will not be prosecuted. ${ }^{100}$

The Truth and Reconciliation Commission on the amnesty took the position that the grant of amnesty was not unreasonable as a condition for ending the conflict in Sierra Leone. ${ }^{101}$

The virtues of amnesty are encapsulated in the Additional Protocol II to the Geneva Conventions of 1977, which applies to non-international armed conflict, Article 6(5) of which states: "At the end of hostilities, the authorities in power shall endeavor to grant the broadest possible amnesty to persons who have participated in the armed conflict, or those deprived of their liberty for reasons related to the armed conflict, whether they are interned or detained."102 The objects of the text as stated by Schabas are to first get combatants from fighting to death by the assurance that they would not be punished if they laid down their arms, and second, to bring about reconciliation, which is needed in a society divided by war. As a matter of fact, the Red Cross' commentary on the text under consideration

100 W.A. Schabas, 'Amnesty, The Sierra Leone Truth and Reconciliation Commission and the Special Court for Sierra Leone', University of California Davis, Vol. 11, No. 145, 2004, pp. 168-169.

101 See Witness to Truth: Report of Truth and Reconciliation Commission for Sierra Leone, 2004.

102 Quoted in Schabas, 2004, p. 167. 
states, "The object of this sub-paragraph is to encourage gestures of reconciliation which can contribute to re-establishing normal relations in the life of a nation which has been divided." 103

In any case, the cases on national amnesties make it clear that amnesties at the national levels have been invalidated by regional and international mechanisms. But the invalidation took place after the purpose of the amnesty had been fulfilled and stability had been maintained in the societies concerned. It is a signal that amnesty when granted may be trumped in the future. This smacks of deception, and warring groups are not likely to lay down their arms on the bait of amnesty.

There is now an upsurge in the determination to pursue prosecution of certain international crimes, and the human rights activists are in arms against the amnestization of such crimes. The idea is that 'there can be no peace without justice' or 'no reconciliation without justice'; justice, being retributive justice. The prevailing position of the international community is to prosecute certain international crimes. Consequently, the ICC is the permanent international court established to prosecute genocide, crimes against humanity, war crimes and crimes of aggression. By implication, therefore, the ICC can trample on amnesty laws at the national level on the crimes within its jurisdiction. Even then it should be noted that the ICC Statute, international human rights law, the Geneva Conventions and other legal texts on international criminal law do not expressly in themselves prohibit amnesty, but rather emphasize the duty to prosecute and punish such crimes.

But in practical terms the ICC's operations have been met with or said to have been thwarted by amnesty. As already pointed out, the Government of Uganda entered into negotiation with the LRA to peacefully settle the conflict while the ICC arrest warrant subsisted. The government decided to grant the LRA amnesty and get the Prosecutor to withdraw the indictment if the negotiations went through. Uganda contemplated utilizing Mato Oput, a traditional justice mechanism, as an alternative justice mechanism to deal with the abuses that took place. This infuriated the ICC and its allies. The Prosecutor maintained that his office would not drop the indictment. ${ }^{104}$ The Government of Uganda was unable to fulfil its treaty obligation to the ICC by its inability to arrest the indicted and hand them over to the ICC. However, it breached its treaty obligations to the ICC by granting the indictees an amnesty for the crimes that they had been indicted for. But given the exigency of the situation, what could the government have done in view of the atrocities being meted out to its citizens? Did it have to stand by its international obligation to the detriment of its primary responsibility to take the necessary steps to protect its citizens even if it meant granting of an amnesty to peacefully settle the conflict? Meanwhile, none of the indictees have been arrested for the ICC. 


\subsubsection{Ongoing National Juridical Processes}

The ICC, being a permanent institution, will coexist and operate alongside other domestic juridical bodies in the places of their intervention. First, there may be a truth commission. The term 'truth commission' is a generic term of recent adoption given to bodies that carry out certain kinds of official inquiry, namely official truth-seeking in respect of past abuses. They are called by different names in different jurisdictions. ${ }^{105}$ A defining characteristic of truth commissions is the absence of trials in their processes. They do not determine criminal responsibility, neither do they punish nor enforce their recommendations. ${ }^{106}$ Moreover, they are not like national human rights institutions set up to deal with persistent human rights issues, but are created on an ad hoc basis in response to a political transition. ${ }^{107}$ Also, truth commissions are usually created in response to amnesty where prosecutions may not be possible, as was the case in South Africa. ${ }^{108}$ They sometimes complement trials and concurrently exist and operate alongside the trial process as was done in Sierra Leone. ${ }^{109}$

In recent times, truth commissions have been largely utilized to provide restorative endeavours in transitional democracies. According to the South African Truth and Reconciliation Commission, their value lies in "their ability to construct a "historic bridge" between "a deeply divided past of untold suffering" and "a future founded on the recognition of human rights". ${ }^{110}$ The fundamental goals of truth commissions have been "to discover, clarify, and formally acknowledge past abuses; to respond to specific needs of victims; to contribute to justice and accountability; to outline institutional responsibility and recommend reforms; and to promote reconciliation and reduce conflict over the past" ${ }^{111}$ Other goals are to find the truth about past events and create an official historical record; establish national reconciliation; secure justice for victims; deter future abuses and violations; and take a fact-finding step towards prosecution. ${ }^{112}$

105 In East Timor it was called the Commission for Reception, Truth and Reconciliation. In Argentina it was referred to as a Commission of the Disappearance of Persons. In Guatemala, it was known as Clarification Commission, in Ghana as National Reconciliation Commission and in some cases it has been referred to as commission of inquiry.

106 P. Hayner, 'Commissioning the Truth: Further Research Questions', Third World Quarterly, Vol. 17, No. 1, 1996, pp. 19-29.

107 Id.

108 Gibson, 2002; M Humphrey, 'From Victimhood: Truth Commissions and Trials as Rituals of Political Transition and Individual Healing', Australian Journal of Anthropology, Vol. 14, No. 2, 2003, pp. 171-188.

109 L. Apori-Nkansah, Transitional Justice in Postconflict Contexts: The Case of Sierra Leone's Dual Accountability Mechanisms (doctoral Dissertation on file at Walden University, 2008).

110 G. Grandin, 'The Instruction of Great Catastrophe: Truth Commissions, National History, and State Formation in Argentina, Chile, and Guatemala', American Historical Review, Vol. 110, No. 1, 2005, pp. 46-67.

111 B.P. Hayner, Unspeakable Truths: Facing the Challenge of Truth Commissions, Routledge, New York 2002, p. 24.

112 M. Scharf, 'The Case for a Permanent International Truth Commission', Duke Journal of Comparative \& International Law, Vol. 7, 1997, pp. 375-410. Retrieved on 20 May 2004 from <www.law. duke.edu/journals/djcil/articles/djcil7p375.htm\#FA0>. 
Truth commissions also fill in the limitations inherent in trials. This is because the purposes served by truth commissions in transitional democracies cannot all be met within the context of trials and other judicial inquiries ${ }^{113}$; for trials concentrate on individual perpetrators, leaving out the victims and socioeconomic, cultural and political underpinnings, which gave rise to the abuses in the first place. ${ }^{114}$ Even in situations where attempts are made to effect trials, the results of convictions have been very limited. As a matter of fact, the Nuremberg trials of Nazi Germany witnessed 85,885 prosecutions but secured only 7,000 convictions. Thus truth processes take care of the shortcomings of trials, but are not substitutes for trials. They, however, serve an essential need in democratic transitions. Moreover, the post-transition contexts within which truth commissions emerge usually signify weak transitional governments, with the outgoing regime still strong on the ground and sometimes with negotiated amnesties. ${ }^{115}$ It thus becomes impossible to embark on trials by the societies involved.

With the ICC's mandate to prosecute war crimes wherever they may occur in states that are parties to the ICC, the situation whereby restorative and punitive mechanisms are employed in respect of the same abuses appears inevitable in the future. It is imperative that these processes are packaged and managed in such a manner as to serve the ends of peace, justice and reconciliation. The experiences between the Special Court for Sierra Leone and the Truth and Reconciliation Commission for Sierra Leone may offer some insights. In their case the TRC statute was in place before the Special Court Statute was enacted. The laws did not address their legal relationship. The laws setting up the two institutions did not delineate their respective jurisdictions concerning exclusive personal, temporal and subject matter jurisdictions. Their mandates overlapped. Thus they both had an interest in the same people and the same issues, as the case may be. As the TRC was calling people for reconciliation, the Special Court was chasing them for prosecution. Their relationship had not been delineated by their laws; the Special Court claimed primacy over the TRC while the TRC claimed parity with the Special Court. This gave rise to unwarranted controversies and tensions in areas that needed to be coordinated for a harmonious coexistence. It brought about a headon collision between them, especially when the TRC sought access to the detainees of the Special Court, leading to a breakdown in their relationship. The public

113 C.T. Call, 'Is Transitional Justice Really Just?', Brown Journal of World Affairs, Vol. 11, No. 1, 2004, pp. 101-133.

114 Tepperman, 2002.

115 Verwoed, 1999. 
became confused and could not appreciate the respective roles of the two institutions in the peace-building process. ${ }^{116}$

On the other hand, the experiences of East Timor, where retributive and restorative mechanisms were coordinated in terms of predicating one on each other, yielded a positive outcome. When East Timor gained her independence from Indonesia, the UN Security Council put in place the UN Transitional Administration in East Timor (UNTAET) to govern and administer that country. UNTAET set up a Serious Crimes Unit within the District Court of Dili, a retributive mechanism, and the Commission for Reception Truth and Reconciliation (CRTR), a restorative mechanism, to deal with abuses that had occurred in a political insurgency in that country. Where the CRTR received statements from perpetrators, they were reviewed to determine whether the perpetrators qualified for community reconciliation. Where the perpetrators qualified they were submitted to the CRTR process. However, where the statement depicted a serious offence, it was referred to the Office of the Prosecutor of the Serious Crimes Unit, and the CRTR discontinued its proceedings in the matter. If the Prosecutor did not act on the referral, the CRTR resumed its proceedings on it. ${ }^{117}$

Doyle also cited Argentina, where few prosecutions took place in conjunction with restorative measures, as a successful case of implementation of the restorative and retributive paradigms. According to her, it served as a strong message against impunity for the other perpetrator groups, provided victims with a sense of justice and sent a signal to the population of a government committed to democracy and the rule of law. ${ }^{118}$ The above cited scenarios provide lessons the ICC could learn from where its operation intersects with a national truth commission. Member states should take cognizance of the ICC's Statute and their obligations when mandating truth commissions so as not to compromise their obligation under the ICC Statute as well as not to undermine the ICC. The coordination arrangement should address issues of implementation of their plans, whether

116 For detailed analyses on the TRC and Special Court for Sierra Leone with regard to their legal and working relationship and the confusion it created on the ordinary person, see T. Perriello \& M. Wierda, International Centre for Transitional Justice, The Special Court for Sierra Leone under Scrutiny, Prosecutions Case Studies Series, 2006. Retrieved on 1 August 2007, from <www. ictj. org/static/ Prosecutions/Sierra. study. pdf>, p. 41; W.A. Schabas, 'The Relationship Between Truth Commissions and International Courts: The Case of Sierra Leone', Human Rights Quarterly, Vol. 25, No. 4, 2003, pp. 1035-1066; W.A. Schabas, 'A Synergistic Relationship: The Sierra Leone Truth and Reconciliation Commission and Special Court for Sierra Leone', in W.A. Schabas \& S. Darcy (Eds.), Truth Commissions and Courts: The Tensions between Criminal Justice and the Search for Truth, Kluwer Academic Publishers, The Netherlands, 2004, pp. 3-54 ; A.TejanCole, 'The Complementary and Conflicting Relationship between the Special Court for Sierra Leone and Truth and Reconciliation Commission', Yale Human Rights and Development Law Journal, Vol. 6, No. 1, 2003, pp. 139-159; Witness to Truth: Report of Truth and Reconciliation Commission for Sierra Leone, 2004; Truth and Reconciliation Working Group and Network Movement for Justice and Development, 2007. An initial study of the performance and impact of the Truth and Reconciliation Commission (Available from National Secretariat, Forum of Conscience, 89 Fort Street. Freetown, Sierra Leone, email foc_sl@yahoo.com).

117 E.M. Evenson, 'Truth and Justice in Sierra Leone: Coordination between Commission and Court', Columbia Law Review, Vol. 104, No. 3, 2004, pp. 730-768.

118 Doyle, 2004. 
their respective processes should run concurrently or sequentially with the restorative process preceding the punitive process or vice versa, the timing of their activities and possible linkages between them on information sharing and witnesses.

Second, there may be national prosecutions in respect of the offences that fall under the jurisdiction of the ICC and vice versa. In such a situation the ICC may not intervene at all since it is to play a complementary role to national prosecutions or it may choose to assist the national court in strengthening its capacity to undertake the trials. This could be in the form of training of judges, police and staff of the judiciary and provision of resources and logistical support. This will strengthen the capacity of national courts for future jurisdiction. After all, states have a primary responsibility to try such cases. Alternatively, state members may limit their jurisdiction to the offences under national law and leave out those offences that are international crimes. Where a situation warrants ICC's intervention, a state may also decline to carry out prosecutions. After all, the ICC comes in when states are unwilling or unable to prosecute. But in a situation where the ICC and national courts exercise concurrent jurisdiction to prosecute war crimes, cooperative functioning becomes key as the administration of justice from an international platform in terms of those the ICC may prosecute has different implications from those who will come under national criminal jurisdiction. For example, the ICC Statute does not make room for the death penalty, but the death penalty is on the statute books of many countries in Africa. A perpetrator indicted by a state may face the death penalty, whereas an indictee by the ICC may be given a term of imprisonment. Thus the prosecution of the same crimes may yield different outcomes. The experiences of Sierra Leone may be insightful. The Special Court for Sierra Leone (SCSL) and the national courts had concurrent jurisdiction, and the national courts were to defer to the SCSL in cases of conflict. ${ }^{119}$ An official of the Attorney General Office in Sierra Leone confirmed that the national courts of Sierra Leone tried offences similar to those tried by the SCSL. ${ }^{120}$ Also, a Rule of Law Specialist with the United Nations Mission of Sierra Leone confirmed this when he observed thus:

they [Government] gave away 13 to the Special Court. They [Government] kept the largest number in jail [...] In 2004 when I was leaving [Sierra Leone], the government had about 117 people in jail who could be sentenced to death for war related offences. Just like those considered to bear the greatest responsibility, those being held in the national prisons had killed and maimed just like those before the Court. However, they were not considered politically high enough to bear the greatest responsibility. ${ }^{121}$

119 Arts. 8 and 9 of the Special Court Statute.

120 Confidential interview with an officer of the Office of the Attorney- General, Sierra Leone in January 2007 in Freetown.

121 A confidential telephone interview with a former rule of law specialist with the United Nations Mission in Serra Leone (UMANSIL), who at the time of the interview was working with the UN Mission in Liberia in March 2007. 
The implication is that people who had committed similar offences may have been subjected to different legal systems or standards of justice as the case may be as well as to different sentencing upon conviction. Thus an accused found guilty of crimes by the SCSL was to suffer a term of imprisonment, a fine or forfeiture of assets with no death penalty, ${ }^{122}$ whereas conviction of the same crime by the national court could warrant the death penalty. ${ }^{123}$ Thus, those found guilty by the SCSL who presumably bear the greatest responsibility had the lesser punishment of imprisonment as opposed to the death penalty, and also presumably had better of conditions of imprisonment. The concurrent jurisdiction of the ICC with the national courts could give rise to divergent norms or different systems of justice. Clear guidelines are needed on the matter to avoid absurdity where the ICC exercises concurrent jurisdiction with national courts. In such a situation, coordination between the country and the ICC is necessary to harmonize their operations; to work out criteria for the scope of their respective jurisdictions. This should not be left to the ICC alone; state parties concerned should also exercise initiative in that direction to ensure the necessary protocol is put in place.

\subsubsection{The Sociocultural Conditions of the People Affected by the War}

The sociocultural conditions of the African people, namely their literacy and economic status, cultural approaches to dispute resolution and their priority concerns vis-à-vis justice are critical factors to their interest, cooperation and support for the ICC. Seeking the views of the populace on the policy choice of justice type as well as its delivery supports the position taken by the United Nations Office of the High Commissioner for Human Rights (OHCHR), namely that the views of those affected by the conflict must be included in the decision to address the abuses in terms of the nature of mechanisms that will best serve their needs.

The OHCHR conducted a survey on the views of Northern Ugandans on matters of accountability for abuses suffered in the conflict that had raged between the Government of Uganda and the LRA for over 20 years, as discussed earlier in this article. It was found, among other things, that the people's priority regarding transitional justice for the abuses they had suffered were truth and compensation. Based on this, the OHCHR advocated that the concerns of those affected by the conflict should form part of the ongoing negotiations between the Ugandan government and the LRA concerning issues about transitional justice. OHCHR pointed out the argument so far about how the issues in the Northern Uganda situation had been drowned in "artificial dichotomies, including peace versus justice, local versus international responses to atrocities, and the population's desire for forgiveness and reconciliation versus punishment". 124 Uganda's Refugee Law

122 Art. 77 of the Statute of the Special Court for Sierra Leone.

123 Death penalty is still on the statute books of Sierra Leone, although the Attorney General and Minister for Justice Franklyn Bai Kargbo, on 2 May 2014, announced to the United Nations Committee against Torture that Sierra Leone intends to abolish the death penalty in no time.

124 Office of the United Nations High Commissioner for Human Rights (OHCHR). 'Making Peace Our Own: Victims' Perception of Accountability, Reconciliation and Transitional Justice', United Nations, 2007. Retrieved on 4 September 2007 from <www.ohchr.org/english/docs/northern_ Uganda_august2007.pdf>, p. i. 
Project reported from their survey that the Alcholi people of Uganda who had been victims of the war were in favour of granting amnesty to perpetrators. This is because they wanted their children back home who had been perpetrators. ${ }^{125}$ What survivors seek, according to Cobban, may be immediate peace and cessation of war, and their perception of justice may also differ from the popular notion of justice. She maintained that in Mozambique and South Africa survivors were generally satisfied with the cessation of hostilities and absence of prosecution. Mahmood Mamdani cited South Africa as a true case of survivors justice based on forgiveness and not forgetting as well as that of Mozambique, which was a settlement. Mahmood argued that those countries would probably not have attained stability if the ICC had been involved in the way they are in Sudan. ${ }^{126}$

The need to pay attention to the voices of those concerned is also critical in informing the investigation of the Prosecutor. The people who experienced the war usually know the perpetrators and what acts and omissions they consider as constituting abuses. This is usually informed by their norms and experiences. This was the case with the SCSL, where justice as instituted and conceptualized by the Special Court was in some respects contradictory to the people's conceptualization of justice. ${ }^{127}$ This should not be ignored by the ICC in their definition and conceptualization of the crimes of the Rome Statutes. The former UN SecretaryGeneral, Kofi Annan, in his discussion of the rule of law and transitional justice in conflict and post-conflict societies maintained that the ideals of justice inhere in cultures and traditions of societies. Hence justice administration, normally designed through formal mechanisms, is not likely to be effective. ${ }^{128}$ Rae advocated the need to contextualize justice by reference to the sociocultural experiences of a given society in terms of the nature and delivery of their justice package. ${ }^{129}$ It is critical that the ICC take these into consideration to be relevant to the communities they serve.

\section{Conclusion and Recommendations}

The prevailing international position in dealing with war crimes and other heinous breaches of human rights is to prosecute and punish the perpetrators. The ICC has a key responsibility to ensure that, but in its complementary capacity to states that have the primary responsibility to deal with impunity on their shores. Even though several African countries supported the ICC initiative, it is clear that the ICC's intervention in Africa has created an impasse between the ICC and some governments in Africa and the $\mathrm{AU}$ as a continental body. The $\mathrm{AU}$ has accused the ICC of engaging in selective justice as its indictments are only in respect of the

125 As cited also in Blumenson, 2006.

126 See Mamdani, 2014.

127 See L.A. Nkansah, 'Justice Within the Arrangement of the Special Court for Sierra Leone versus Local Perceptions of Justice: A Contradiction or Harmonious?', African Journal of International and Comparative Law, Vol. 22, No. 1, 2014, pp. 103-119.

128 Report of the Secretary-General on the rule of law and transitional justice, 2004, p. 4.

129 Rae, 2005. 
conflict situations in Africa. The AU has also expressed misgivings about the indictment and trial of some sitting heads of states in Africa. The trial/ indictment of heads of states in Africa has serious constitutional and political implications. Even though the AU as a body is not a party to the ICC framework, its stands have affected the cooperation of some of its members with the ICC negatively.

Some governments in Africa have been unwilling to comply with their obligations under the Rome Statute. Again, it came out clearly that the political exigencies occasioned by intractable conditions in some countries made it difficult, if not impossible, for the governments concerned to comply with their obligations under the ICC. Available evidence makes it clear that the ICC's intervention in African situations are in response to inhuman abuses that governments have not effectively taken steps to stop or to prevent.

However, the ICC has failed to pay attention to the domestic contexts of its operations, and as a result it has impeded the peace-building process in some of the places of its intervention, especially where there is an ongoing conflict and the indictees have not been subdued. Countries whose governments have subdued those indicted are able to cooperate with the ICC, and there appears to be relative calm in such places. The ICC's operations have serious constitutional and political implications that cannot be ignored.

The ICC, being a permanent institution, is likely to coexist and operate alongside other domestic juridical bodies in the places of their intervention. There may be national trials involving war crimes, truth commissions or existing peace agreements at the national level. It is critical that the ICC coordinates its plans taking into consideration these other bodies, with the understanding that they are different parts of the same tool. Otherwise the ICC and these other bodies will remain pitted against each other, undermine their respective mandates and create tensions in their efforts to implement their plans.

The sociocultural conditions of the African people, namely their literacy and economic status, cultural approaches to dispute resolution and their priority concerns vis-à-vis justice are critical factors to their interest, cooperation and support for the ICC. It seems the ICC has not given any consideration to these dynamics so far. On the basis of the foregoing, the following measures are recommended as the way forward:

1 African governments that are parties to the Rome Statute should comply with their treaty obligations under the ICC's Statute without reservation;

2 There is a need for the ICC to dialogue with the AU to end the squabble between them since the AU's support is critical to the effectiveness of the ICC. Similarly, the AU member states have to respect their treaty obligations to the ICC;

3 The ICC and stakeholders should balance the obvious need for security with that of justice in terms of expediency. Timing is critical in situations where the ICC's intervention becomes necessary; otherwise the effect will be counterproductive; 
4 The ICC should not ignore domestic political exigencies in the pursuit of justice in the wake of a violent conflict. Purely political questions should not be settled on the altar of justice;

5 State Parties should ensure that in mandating truth commissions, peace agreements, etc. they do not undermine their obligations to the ICC;

6 Coordination between the ICC and other justice mechanisms in the places of their intervention is critical for the effective functioning of the ICC and those bodies;

7 The ICC should reach out to the African people on the ICC's mandate in a way that will let them understand the process and possibly identify with it. 